\title{
Investigation of Effect of Graphite Particles on Drillability of Metal Matrix Composite
}

\author{
Saravanakumar ARUNACHALAM, Sasikumar PERUMAL * \\ Department of Mechanical Engineering, KPR Institute of Engineering \&Technology, Coimbatore - 641407, India
}

cross $^{\text {ref }}$ http://dx.doi.org/10.5755/j01.ms.22.3.9724

\section{Received 29 January 2015; accepted 24 July 2015}

\begin{abstract}
The present article investigates the effect of graphite particles in the drilling of hybrid aluminium matrix composites (AMCs) using TiN coated carbide drills. Materials used for the present investigation are Al6063-aluminum alloy reinforced with alumina of size 20 microns and graphite of an average size 75 microns, which are produced through stir casting method. Experiments are conducted based on Taguchi's method L27 orthogonal array on a vertical machining centre. A model is developed to correlate the drilling parameters with burr height and surface roughness using regression analysis. The results indicate that the developed model is suitable for prediction of burr height and surface roughness in drilling of hybrid AMCs.The influence of different parameters on Surface roughness and burr height of $\mathrm{Al} 6063 / \mathrm{Al}_{2} \mathrm{O}_{3 \mathrm{p}} / \mathrm{Gr}_{\mathrm{p}}$ composites has been analyzed through ANOVA table and contour graphs.

Keywords: drilling, Taguchi method, burr height, surface roughness, regression analysis.
\end{abstract}

\section{INTRODUCTION}

Mechanical characteristics of aluminium matrix composites (AMC) such as improved strength to weight ratio, stiffness and wear resistance indicates that these composites play important role in application for engineering components from automotive to aircraft. In recent years, applications of these aluminium matrix composites are the most important developments in composite engineering field, particle-reinforced aluminium alloy composites are one among them [1,2]. However, application of ceramic particle reinforced aluminium alloy composite is limited by their poor machinability. Mostly aluminium alloy reinforced with ceramic particles like alumina and $\mathrm{SiC}$, which are highly abrasive in nature. Addition of ceramic particulates increases both mechanical strength and wear resistance of $\mathrm{Al}$ alloy. But the consequent increase of hard ceramic particles in the AMCs, makes them difficult to machine as they lead to tool wear and improper surface finish with increased machining cost $[3,4]$. Drilling is the one of the important machining process used in all type of engineering applications for fastening and riveting purposes. While drilling AMCs, it creates several manufacturing problems such as high drilling forces, tool wear, poor surface finish and burr formation [5].

In this scenario to improve the machinability, AMCs reinforced with solid lubricant such as graphite particulates as a second reinforcement effectively improves the machinability with reduced cutting forces [6]. Songmene and Balazinzki [7] and Basavarajappa et al. [8] reported that hardness and strength of the composites are reduced due to the inclusion of graphite (Gr) in $\mathrm{Al} / \mathrm{SiCp}$ composites, which is favorable for machinability. Sharma et al. [9] studied the drilling of zinc/graphitic metal matrix

\footnotetext{
* Corresponding author. Tel.: +91-9443940070 ; fax: +91-0422-2635666.

E-mail address: sasi_me75@yahoo.com (S. Perumal)
}

composites with HSS drill and concluded that tool life gets increased while machining graphite reinforced aluminium matrix composites compared to the base alloy. Since graphite acts as a solid lubricant, it reduces the friction at tool-work interface. Due to this action a small amount of energy is required for drilling the composite compared to the base alloy. Basavarajappa and Paulo Davim [10] investigated the turning of Al2219/15SiCp and Al2219/15SiCp-3Gr (hybrid) composites on surface roughness and chip formation. It was concluded that incorporation of graphite in Al2219/15SiCp composite produced discontinuous chips leading to easy machining and graphite particles creates deep valleys and pits on the machined surface which increases the surface roughness values.

Shanmughasundaram and Subramanian [11] studied the effect of the step drill's geometries and cutting parameters on the exit burr height in drilling of $\mathrm{Al}-\mathrm{Gr}$ composites. Taguchi method L27 orthogonal array used to find the optimum drilling parameters and with the help of analysis of variance (ANOVA) investigated the influence of parameters on the burr height of composites. Palanikumar and Muniaraj [12] discussed the drilling parameter influence on thrust force in drilling of $\mathrm{Al} 6061 / 15 \% \mathrm{SiC} / 4 \% \mathrm{Gr}$ metal matrix composites using Tin coated solid carbide drills. Results revealed that thrust force is greatly influenced by the feed rate rather than spindle speed and diameter of drill. Yahya Altunpak [13] fabricated two different metal matrix composites $\mathrm{Al} / 20 \% \mathrm{SiC} / 5 \% \mathrm{Gr}$ and $\mathrm{Al} / 20 \% \mathrm{SiC} / 10 \% \mathrm{Gr}$ by vortex method and performed drilling on them with diamond-like carbon coated cutting tools. They reported that surface roughness value of $\mathrm{Al} / 20 \% \mathrm{SiC} / 5 \% \mathrm{Gr}$ composite are relatively less when compared to $\mathrm{Al} / 20 \% \mathrm{SiC} / 10 \% \mathrm{Gr}$ composite. Further it is noted that feed rate is the main factor, which influences the surface roughness and cutting force in both composites. Sivasankaran [14] worked on 
turning of $\mathrm{AA} 7075 / 3 \% \mathrm{ZrB}_{2}$ and reported that addition of $1 \%$ graphite particle with $\mathrm{AA} 7075 / 3 \% \mathrm{ZrB}_{2}$ improves the surface quality of the machined parts. AA7075/3\% $\mathrm{ZrB}_{2}$ composite possessed higher hardness and flexural strength value than $\mathrm{AA} 7075 / 3 \% \quad \mathrm{ZrB}_{2} / 1 \% \mathrm{Gr}$ composite which improves the machinability of graphitic composite. Basavarajappa et al. [15] studied formation of burr in drilling of $\mathrm{Al} 2219 / 15 \mathrm{SiCp}$ and $\mathrm{Al} 2219 / 15 \mathrm{SiCp} / 3 \mathrm{Gr}$ using solid carbide multifacet drills. Results indicated that formation of burr in graphitic composite is less when compared to the $\mathrm{SiCp}$ and discontinuous chips formed which is advantageous for machining of graphitic composite. Rajmohan et al. [16] have used Taguchi method of experimental design and analyzed the drilling of hybrid aluminium metal matrix composites using the greyfuzzy algorithm. They have concluded that addition of $3 \%$ of mica to $\mathrm{Al} 356 / \mathrm{SiC}$ helps in reducing the burr height and reduces the thrust forces significantly which is attributed to the solid lubricating property of mica. Based on the literature review, it was found that there is a lot of research work done using more than $3 \%$ graphite. Graphite composed of planes of weaker carbon atoms is structurally hexagonal in orientation. Only little force is needed to separate layers of graphite [17]. Hence, in this study, graphite with less than $3 \%$ is used to fabricate the hybrid AMC and its effect is investigated on drilled holes in terms of burr height and surface roughness.

\section{MATERIALS AND METHODS}

\subsection{Materials}

Aluminum alloy 6063 is used as the matrix material. The matrix alloy has a composition (\% by weight) $\mathrm{Si}$ (0.43), $\mathrm{Cu}$ (0.015), Fe (0.27), $\mathrm{Mn}$ (0.02), $\mathrm{Mg}(0.43)$, $\mathrm{Zn}(0.0024), \mathrm{Ti}(0.008), \mathrm{Cr}(0.005)$ and $\mathrm{Al}$ (balance). Al6063 reinforced with alumina particles size of 20 microns and graphite particles are added as second reinforcement with the average particle size of 75 microns for fabrication. The composites fabrication is carried out with $0-2 \mathrm{wt} . \%$ of $\mathrm{Gr}$ particles in steps of $1 \mathrm{wt} . \%$. The alumina particles used is fixed quantity of $6 \mathrm{wt} . \%$. The composites are fabricated using stir casting method at an optimal speed ensuring that the reinforcements are uniformly distributed within the matrix material. Small pieces of aluminum alloy were melted using Induction electric resistance furnace. Preheated reinforcements $\mathrm{Al}_{2} \mathrm{O}_{3}$ and $\mathrm{Gr}$ particles were added with molten metal of $\mathrm{Al}$ alloy at $800{ }^{\circ} \mathrm{C}$ and stirred continuously. To remove the unwanted gases, Hexa-Chloro Ethane $\left(\mathrm{C}_{2} \mathrm{Cl}_{6}\right)$ degassing tablets were added to it. The stirring was continued for 7 minutes at $465 \mathrm{rpm}$. After this, molten alloy was poured into preheated mould and cooled in atmospheric air.

\subsection{Experimental setup}

Drilling tests are carried out on FEELER FV-800A vertical machining center. The machining samples are prepared in the form of $100 \mathrm{~mm}$ x $25 \mathrm{~mm}$ x $10 \mathrm{~mm}$ blocks for each material. A $6 \mathrm{~mm}$ diameter TiN coated solid carbide drill with $20^{\circ}$ helix angle and $118^{\circ}$ point angle is used in the experiments. The surface roughness of the workpiece is measured by using a ZEISS surface roughness tester of HANDYSURFE-35B.

Table 1. Drilling parameters and its levels

\begin{tabular}{|c|c|c|c|}
\hline Levels & Speed A, rpm & Feed B, $\mathrm{mm} / \mathrm{min}$ & wt.\% of Gr C \\
\hline 1 & 1000 & 50 & 0 \\
\hline 2 & 2000 & 100 & 1 \\
\hline 3 & 3000 & 150 & 2 \\
\hline
\end{tabular}

$$
\text { a }
$$

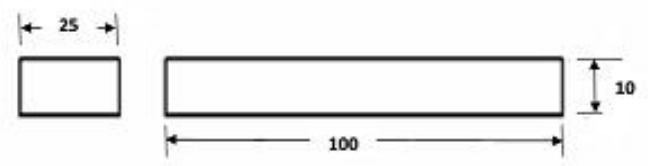

b

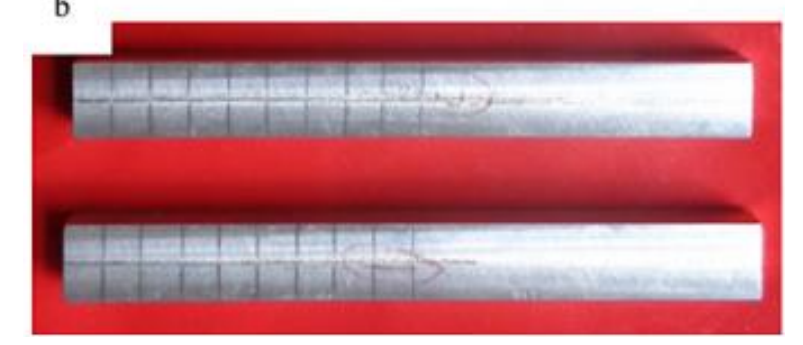

Fig. 1. a - workpiece drawing; b - prepared samples

Surface roughness measurement direction is perpendicular to the hole circumference. The surface roughness values given in this study are the average of three measurements taken from the same hole surface. The burr heights (exit) of drilled holes are measured using a SP-300 SIPCON profile projector. Three different points of exit burr height for each hole are measured. In each holes the distance of the highest level of burr height is measured then the average of these values are taken. The drilling experiments were performed at different spindle speed of $1000 \mathrm{rpm}, 2000 \mathrm{rpm}$ and $3000 \mathrm{rpm}$ with feed rates of $50 \mathrm{~mm} / \mathrm{min}, 100 \mathrm{~mm} / \mathrm{min}$ and $150 \mathrm{~mm} / \mathrm{min}$ are carried out using $6 \mathrm{~mm}$ TiN coated solid carbide twist drill. Table 1 indicates the drilling parameters and their levels.

\subsection{Plan of experiments}

Information such as the main and interaction factor effects, setting the minimum number of experiments are found using the Taguchi experimental design. The Taguchi method uses $\mathrm{S} / \mathrm{N}$ (signal to noise) ratio to find out the best combination of design parameters with minimum variation from any of the functions such as "the-smaller the-better", or "'the-nominal-the-best" or "'the-larger-the-better', There are few other advantages such as saving of effort in conducting experiments, saving experimental time, reducing the cost and discovering significant factors quickly [18]. For the plan of experiments, Taguchi methods with three factors at three levels were used. Orthogonal array of L27 $\left(3^{3}\right)$ was chosen, which has 13 columns at three levels in which first column is assigned to spindle speed (V), the second column feed rate (f), the fifth column to Percentage of graphite and the remaining columns were used for interaction and other effects. The response factors considered in the present study are surface finish and exit burr height. Table 2 shows the experimental plan and the results obtained for various levels of drilling parameters. During the drilling process, the chips were collected and examined for general characteristics. 
Table 2. Experimental values of burr height and surface roughness

\begin{tabular}{|c|c|c|c|c|c|c|c|c|c|}
\hline \multicolumn{3}{|c|}{ Actual value } & \multicolumn{3}{c|}{ Coded value } & \multicolumn{2}{c|}{ Burr height, mm } & \multicolumn{2}{c|}{ Surface roughness, $\mu \mathrm{m}$} \\
\hline Speed & Feed & Graphite & A & B & C & BH & BH-S/N & SR & SR-S/N \\
\hline 1000 & 50 & 0 & 1 & 1 & 1 & 0.49 & 6.20 & 2.8 & -8.94 \\
\hline 1000 & 50 & 1 & 1 & 1 & 2 & 0.26 & 11.70 & 2.3 & -7.23 \\
\hline 1000 & 50 & 2 & 1 & 1 & 3 & 0.17 & 15.39 & 2.6 & -8.30 \\
\hline 1000 & 100 & 0 & 1 & 2 & 1 & 0.67 & 3.48 & 3.59 & -11.10 \\
\hline 1000 & 100 & 1 & 1 & 2 & 2 & 0.385 & 8.29 & 3.3 & -10.37 \\
\hline 1000 & 100 & 2 & 1 & 2 & 3 & 0.28 & 11.06 & 3.55 & -11.00 \\
\hline 1000 & 150 & 0 & 1 & 3 & 1 & 0.675 & 3.41 & 4.18 & -12.42 \\
\hline 1000 & 150 & 1 & 1 & 3 & 2 & 0.47 & 6.56 & 4.1 & -12.26 \\
\hline 1000 & 150 & 2 & 1 & 3 & 3 & 0.425 & 7.43 & 4.22 & -12.51 \\
\hline 2000 & 50 & 0 & 2 & 1 & 1 & 0.423 & 7.47 & 2.35 & -7.42 \\
\hline 2000 & 50 & 1 & 2 & 1 & 2 & 0.165 & 15.65 & 1.9 & -5.58 \\
\hline 2000 & 50 & 2 & 2 & 1 & 3 & 0.115 & 18.79 & 2.1 & -6.44 \\
\hline 2000 & 100 & 0 & 2 & 2 & 1 & 0.53 & 5.51 & 2.72 & -8.69 \\
\hline 2000 & 100 & 1 & 2 & 2 & 2 & 0.246 & 12.18 & 2.6 & -8.30 \\
\hline 2000 & 100 & 2 & 2 & 2 & 3 & 0.21 & 13.56 & 2.78 & -8.88 \\
\hline 2000 & 150 & 0 & 2 & 3 & 1 & 0.575 & 4.81 & 3.84 & -11.69 \\
\hline 2000 & 150 & 1 & 2 & 3 & 2 & 0.265 & 11.54 & 3.73 & -11.43 \\
\hline 2000 & 150 & 2 & 2 & 3 & 3 & 0.205 & 13.76 & 3.89 & -11.80 \\
\hline 3000 & 50 & 0 & 3 & 1 & 1 & 0.395 & 8.07 & 1.85 & -5.34 \\
\hline 3000 & 50 & 1 & 3 & 1 & 2 & 0.123 & 18.20 & 1.64 & -4.30 \\
\hline 3000 & 50 & 2 & 3 & 1 & 3 & 0.077 & 22.27 & 1.7 & -4.61 \\
\hline 3000 & 100 & 0 & 3 & 2 & 1 & 0.405 & 7.85 & 3.06 & -9.71 \\
\hline 3000 & 100 & 1 & 3 & 2 & 2 & 0.16 & 15.92 & 2.9 & -9.25 \\
\hline 3000 & 100 & 2 & 3 & 2 & 3 & 0.11 & 19.17 & 3 & -9.54 \\
\hline 3000 & 150 & 0 & 3 & 3 & 1 & 0.42 & 7.54 & 3.59 & -11.10 \\
\hline 3000 & 150 & 1 & 3 & 3 & 2 & 0.195 & 14.20 & 3.4 & -10.63 \\
\hline 3000 & 150 & 2 & 3 & 3 & 3 & 0.105 & 19.58 & 3.6 & -11.13 \\
\hline
\end{tabular}

\subsection{Chip morphology}

The drilling of $\mathrm{Al}_{2} \mathrm{O}_{3}$ and graphite particles reinforced aluminum composites results in various types of chip formation from Fig. 2 it can be observed that while drilling $\mathrm{Al} / 6 \% \mathrm{Al}_{2} \mathrm{O}_{3}$ continuous spiral shaped chip with shining surface formed at spindle speed $3000 \mathrm{rpm}$ and feed $50 \mathrm{~mm} / \mathrm{min}$.

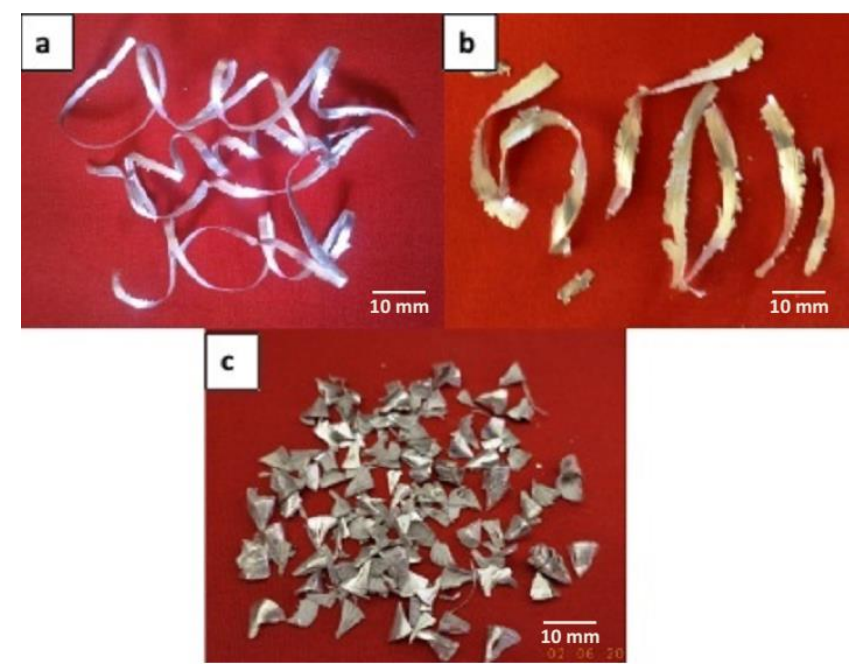

Fig. 2. Chip formed: $\mathrm{a}-\mathrm{Al} / 6 \% \mathrm{Al}_{2} \mathrm{O}_{3} ; \mathrm{b}-\mathrm{Al} / 6 \% \mathrm{Al}_{2} \mathrm{O}_{3} / 1 \% \mathrm{Gr}$; $\mathrm{c}-\mathrm{Al} / 6 \% \mathrm{Al}_{2} \mathrm{O}_{3} / 2 \% \mathrm{Gr}$

For the same machining condition chips formed when drilling of graphitic composites are similar except that chips are very shorter in length for $2 \mathrm{wt} \%$ of graphitic composites and cracks are formed on the outer edge surface of the discontinuous chips formed during machining of $1 \mathrm{wt} \%$ of graphitic composites. The graphitic composites produce discontinuous chips, which lead to easy machining of ceramic particles reinforced composite material [15]. From the study of chip morphology it is noted that graphite reinforced composite chips are short in length and no curls are formed which makes easier for disposal from the machined surface. Hence chips produced by graphitic composite are helpful to improve the machinability.

\section{RESULTS AND DISCUSSION}

In drilling, the lower surface roughness and minimum burr height is the indication of better performance. Therefore, "smaller the-better' concept for the surface roughness and burr height was selected for obtaining optimum drilling parameters. The $\mathrm{S} / \mathrm{N}$ ratios were calculated using MINITAB 16 for each experimental parameters based on the-smaller the-better function of Taguchi method $[15,18]$. The assessment of factors carried out through (i) main effects plot (ii) response table (iii) analysis of variance (ANOVA) technique.

\subsection{Main effect plot}

While drilling of composite material, burr is generated which is plastically deformed material both end of the hole. These generated burrs lead to severe problems in quality of product assembly and performance as they can cause jamming effect between assemblies of parts. From the main effect plot of burr height in Fig. 3, it is noted that 
the burr height is decreased with increase in spindle speed predominantly and increase in burr height with increase in feed rate. Further it shows that increase in graphite content drastically reduces the burr height. Ko and Lee [19] reported that machined parts properties influencing more than feed rate and other cutting parameters. Burr height and thickness will depend on the alloy composition and conditions, its mechanical properties of the work piece material [20]. Addition of graphite particles as a second reinforcement with $\mathrm{Al} / \mathrm{Al}_{2} \mathrm{O}_{3}$ composite helps the material to shear easily and formation of discontinuous chip during the drilling of the composites.

When drilling of graphitic composite material at low feed rate, the cutting force encountered by the material is too low and it leads to reduced plastic deformation. When the plastic deformation takes place, graphite particles smear before the bending of material due to low interfacial bond strength and cutting is prolonged.

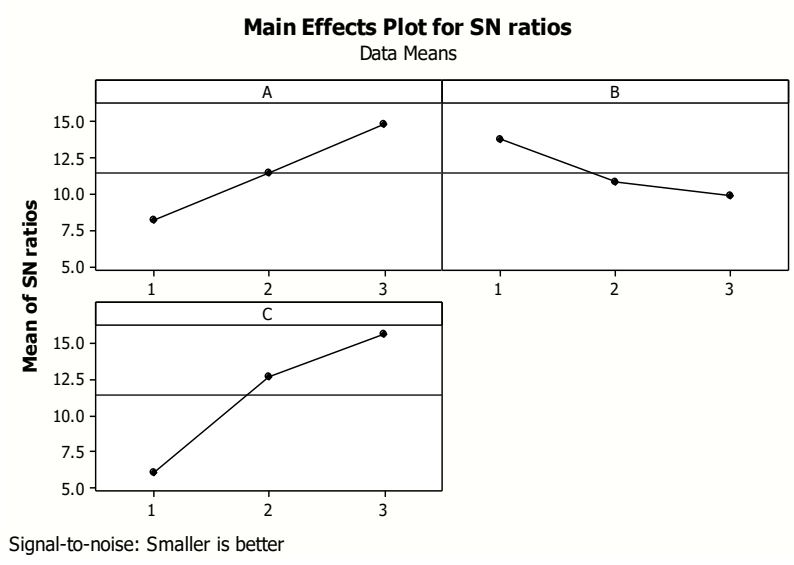

Fig. 3. Main effect plot for burr height

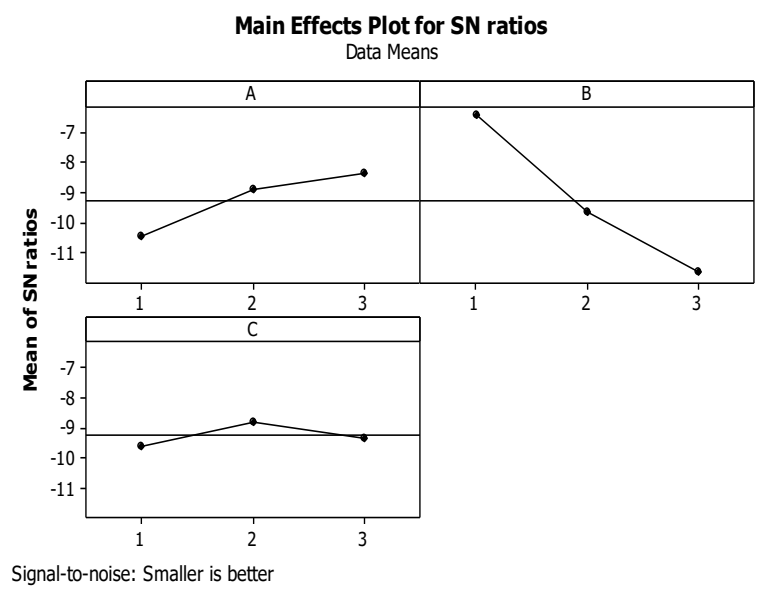

Fig. 4. Main effect plot for surface roughness

As the drilling extends and reinforcement particles form pivot points, a burr of reduced height is formed [21]. Similarly, in this research, addition of graphite particles with $\mathrm{Al} / \mathrm{Al}_{2} \mathrm{O}_{3}$ composite reduces the burr height considerably. Better result obtained at higher spindle speed, lower feed rate and 2 wt. $\%$ of graphite.

Surface roughness main effect plot shows signal to noise ratio for all the levels of selected drilling process parameters in Fig. 4. It is evident that the surface roughness is decreased with increase in spindle speed and increased with increase in feed rate for all the composites. The drilled hole surface finish is improved with $1 \mathrm{wt} . \%$ of graphite particles whereas, increasing further reduces the surface finish of the drilled hole. The surface roughness main effect plot results are in agreement with other researches [10]. Surface roughness values of $\mathrm{Al} / 6 \% \mathrm{Al}_{2} \mathrm{O}_{3} / 2 \% \mathrm{Gr}$ composite are relatively more when compared to $\mathrm{Al} / 6 \% \mathrm{Al}_{2} \mathrm{O}_{3} / 1 \% \mathrm{Gr}$ composite for all cutting conditions. The higher surface roughness values for $\mathrm{Al} / 6 \% \mathrm{Al}_{2} \mathrm{O}_{3} / 2 \% \mathrm{Gr}$ composite are attributed to the easy pullout of graphite between the workpiece and the tool. The removed graphite particles crushed over the machined surface, which form a deep valley and hence increase the surface roughness of the material.

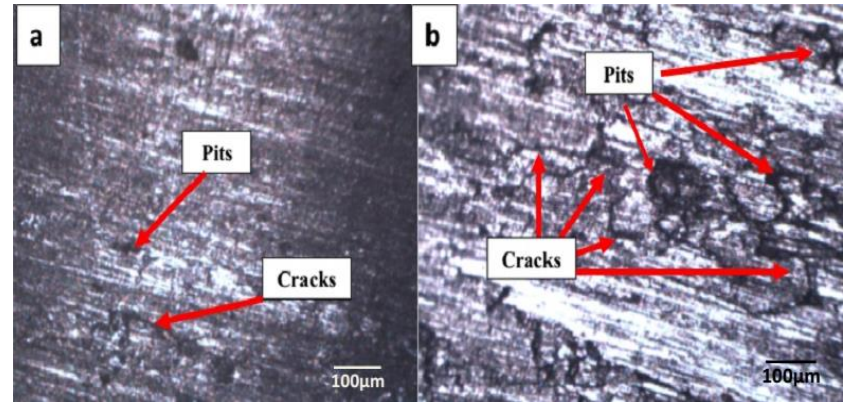

Fig. 5. Drilled hole surface of $\mathrm{a}-\mathrm{Al} / 6 \% \mathrm{Al}_{2} \mathrm{O}_{3} / 1 \% \mathrm{Gr}$; $\mathrm{b}-\mathrm{Al} / 6 \% \mathrm{Al}_{2} \mathrm{O}_{3} / 2 \% \mathrm{Gr}$

Optical microscope analyses have revealed that deep valleys, scratches and fine grooves have been observed over the machined surface of the $\mathrm{Al} / 6 \% \mathrm{Al}_{2} \mathrm{O}_{3} / 2 \% \mathrm{Gr}$ composite. Micro cracks and pits (Fig.5) are also observed on both the composites. Fig. $5 \mathrm{~b}$ shows the existence of more cracks on the surface of the drilled hole on the $2 \% \mathrm{Gr}$ composites. Comparing Fig. 5 a with Fig. 5 b, it can be seen that the amount of cracks and pits are less on the machined surface of $\mathrm{Al} / 6 \% \mathrm{Al}_{2} \mathrm{O}_{3} / 1 \% \mathrm{Gr}$ composite. Lowest surface roughness value observed from low feed rate $(50 \mathrm{~mm} / \mathrm{min})$, higher spindle speed $(3000 \mathrm{rpm})$ and 1 wt.\% of Graphite.

\subsection{Response table}

To measure the quality characteristics, signal to noise ratios were calculated for each experimental result. The influence of control parameters such as spindle speed, feed rate, percentage of graphite on burr height and surface roughness has been analysed using signal to noise response table. The ranking of drilling process parameters using signal to noise ratios obtained for different parameter levels for burr height and surface roughness are given in Table 3 and Table 4 respectively. The control factors are statistically significant in the signal to noise ratio and it could be observed that the percentage of graphite is a dominant parameter on the burr height and feed on surface roughness.

\subsection{Analysis of variance}

Analysis of variance (ANOVA) is used to analyze the influence of drilling process parameters like spindle speed, feed and percentage of graphite on the burr height and surface roughness. Percentage of contribution of each factors are also calculated from ANOVA table values. 
From the Table 5 it is found that graphite particle $(\mathrm{P}=58.04 \%)$ is the most significant factor, whereas speed has $25.8 \%$ contribution and feed has $9.82 \%$ contribution towards the burr height of exit hole. Other interaction are above the confidence level of 0.05 , therefore those interactions can be neglected.

Table 3. Response table for burr height-smaller is better

\begin{tabular}{|c|c|c|c|}
\hline Level & Speed A & Feed B & Graphite C \\
\hline 1 & 8.169 & 13.749 & 6.037 \\
\hline 2 & 11.474 & 10.780 & 12.693 \\
\hline 3 & 14.755 & 9.869 & 15.667 \\
\hline Delta & 6.586 & 3.880 & 9.630 \\
\hline Rank & 2 & 3 & 1 \\
\hline
\end{tabular}

Table 4. Response table for surface roughness

\begin{tabular}{|c|c|c|c|}
\hline Level & Speed A & Feed B & Graphite C \\
\hline 1 & -10.460 & -6.463 & -9.603 \\
\hline 2 & -8.915 & -9.650 & -8.816 \\
\hline 3 & -8.401 & -11.663 & -9.357 \\
\hline Delta & 2.059 & 5.199 & 0.787 \\
\hline Rank & 2 & 1 & 3 \\
\hline
\end{tabular}

However, the interaction between Spindlespeed $X$ feed is $0.96 \%$, spindle speed $\mathrm{X}$ graphite is $3.41 \%$ and feed $\mathrm{X}$ graphite has $1.26 \%$ contribution. Total error associated in this analysis is approximately about $3.35 \%$. It was clear that graphite particles played a major role in reducing the burr height of hybrid aluminium matrix composite. Further from ANOVA table 6 of surface roughness, it is observed that feed has the highest influence on surface roughness with $79.2 \%$ of contribution and followed by speed $13.2 \%$ contribution and graphite particles $1.9 \%$ contribution. The interaction terms have little effect on surface roughness and the residual errors accounts only $0.2 \%$. From the analysis of variance and $\mathrm{S} / \mathrm{N}$ ratio, it is concluded that the graphite particles have the highest contribution on burr height and feed on surface roughness.

\subsection{MULTIPLE REGRESSION ANALYSIS}

A multiple linear regression model gives the relationship between an independent variable and a response variable by fitting a linear equation to observed data. The correlations between the drilling process parameters and the measured response variables (burr height, surface roughness) were obtained by multiple linear regression. Least squares method utilized in regression analysis to the experimental data in order to obtain the coefficients of model. Regression equation is established in terms of coded values represented by Eq. 1 and Eq. 2 for burr height and surface roughness respectively.

The competence of the developed regression model can be verified by using regression spread range. It can be noted that regression spread range (R-Sq) for the burr height model is $98.8 \%$ where as adjusted $\mathrm{R}-\mathrm{Sq}$ is 98.1 and for the surface roughness model regression spread range is (R-Sq) $97.1 \%$ where as adjusted $\mathrm{R}-\mathrm{Sq}$ is $95.3 \%$. F-criterion values are calculated for the developed regression models. For surface roughness, experimental F-criterion value is 53.45 and for the burr height 132.59 .

Table 5. Analysis of variance for burr height

\begin{tabular}{|c|c|c|c|c|c|c|}
\hline Source & DF & Seq.SS & Adj.MS & F & P & Pc \\
\hline Speed & 2 & 195.186 & 97.593 & 166.43 & 0.000 & 25.88 \\
\hline Feed & 2 & 74.082 & 37.041 & 63.17 & 0.000 & 9.82 \\
\hline Graphite & 2 & 437.624 & 218.812 & 373.16 & 0.000 & 58.04 \\
\hline Speed*Feed & 4 & 7.209 & 1.802 & 3.07 & 0.083 & 0.96 \\
\hline Speed*Graphite & 4 & 25.739 & 6.434 & 10.97 & 0.002 & 3.41 \\
\hline Feed*Graphite & 4 & 9.537 & 2.384 & 4.07 & 0.043 & 1.26 \\
\hline Residual Error & 8 & 4.691 & 0.586 & & & 0.62 \\
\hline Total & 26 & 754.066 & & & & \\
\hline
\end{tabular}

Table 6. Analysis of variance for surface roughness

\begin{tabular}{|c|c|c|c|c|c|c|}
\hline Source & DF & Seq.SS & Adj.MS & F & P & Pc \\
\hline Speed & 2 & 20.668 & 10.334 & 311.62 & 0.000 & $13.2 \%$ \\
\hline Feed & 2 & 123.728 & 61.864 & 1865.51 & 0.000 & $79.2 \%$ \\
\hline Graphite & 2 & 2.918 & 1.4591 & 44 & 0.000 & $1.9 \%$ \\
\hline Speed*Feed & 4 & 7.263 & 1.8158 & 54.75 & 0.000 & $4.6 \%$ \\
\hline Speed*Graphite & 4 & 0.074 & 0.0185 & 0.56 & 0.701 & $0.05 \%$ \\
\hline Feed*Graphite & 4 & 1.377 & 0.3444 & 10.38 & 0.003 & $0.9 \%$ \\
\hline Residual Error & 8 & 0.265 & 0.0332 & & & $0.2 \%$ \\
\hline Total & 26 & 156.294 & & & \\
\hline
\end{tabular}

Table 7. Optimal parameters test results

\begin{tabular}{|c|c|c|c|c|c|c|c|}
\hline \multicolumn{3}{|c|}{ Surface roughness $(\mu \mathrm{m})$} & \multicolumn{4}{c|}{ Burr height $(\mathrm{mm})$} \\
\hline \multicolumn{2}{|c|}{ Initial level } & \multicolumn{2}{|c|}{ Optimal level } & \multicolumn{2}{c|}{ Initial level } & \multicolumn{3}{c|}{ Optimal level } \\
\hline $\mathrm{A} 1 \mathrm{~B} 1 \mathrm{C} 1$ & 2.8 & $\mathrm{~A} 3 \mathrm{~B} 1 \mathrm{C} 2$ & 1.64 & $\mathrm{~A} 1 \mathrm{~B} 1 \mathrm{C} 1$ & 0.49 & A3B1C3 & 0.077 \\
\hline
\end{tabular}

Table 8. Confirmation test results

\begin{tabular}{|c|c|c|c|c|c|c|c|}
\hline \multicolumn{4}{|c|}{ Surface roughness, $\mu \mathrm{m}$} & \multicolumn{3}{c|}{ Burr height, $\mathrm{mm}$} \\
\hline Optimal parameters & Experimental & Predicted & $\%$ Error & Optimal parameters & Experimental & Predicted & $\%$ Error \\
\hline A3B1C2 & 1.64 & 1.70 & $3.6 \%$ & A3B1C3 & 0.077 & 0.08 & $2.3 \%$ \\
\hline
\end{tabular}


It is observed that for both models Experimental Fcriterion value is greater than the value of theoretical Fcriterion $\left(\mathrm{F}_{(0.05,10,16)}=2.4935\right)$.

Hence the developed model is statistically significant, meaning that regression model is useful [22]. Also the R$\mathrm{Sq}$ values are reasonably close to unity, models provide reasonably good explanation of the relationship between the independent variables and response variables.

The regression equation for burr height is:

$\mathrm{BH}=0.929-0.130 \mathrm{~A}+0.212 \mathrm{~B}-0.588 \mathrm{C}-0.0270 \mathrm{AB}+$ $0.0194 \mathrm{AC}+0.0177 \mathrm{BC}+0.0193 \mathrm{AA}-0.0244 \mathrm{BB}+$ $0.0968 \mathrm{CC}-0.00838 \mathrm{ABC}$

The regression equation for surface roughness is:

$\mathrm{SR}=3.66-1.26 \mathrm{~A}+0.863 \mathrm{~B}-1.00 \mathrm{C}+0.070 \mathrm{AB}+$ $0.020 \mathrm{AC}+0.078 \mathrm{BC}+0.198 \mathrm{AA}-0.0672 \mathrm{BB}+0.204$ $\mathrm{CC}-0.0100 \mathrm{ABC}$

The burr height and surface roughness values are calculated using the developed equation for all predictions and compared with the experimental results, which are shown in Fig.6.
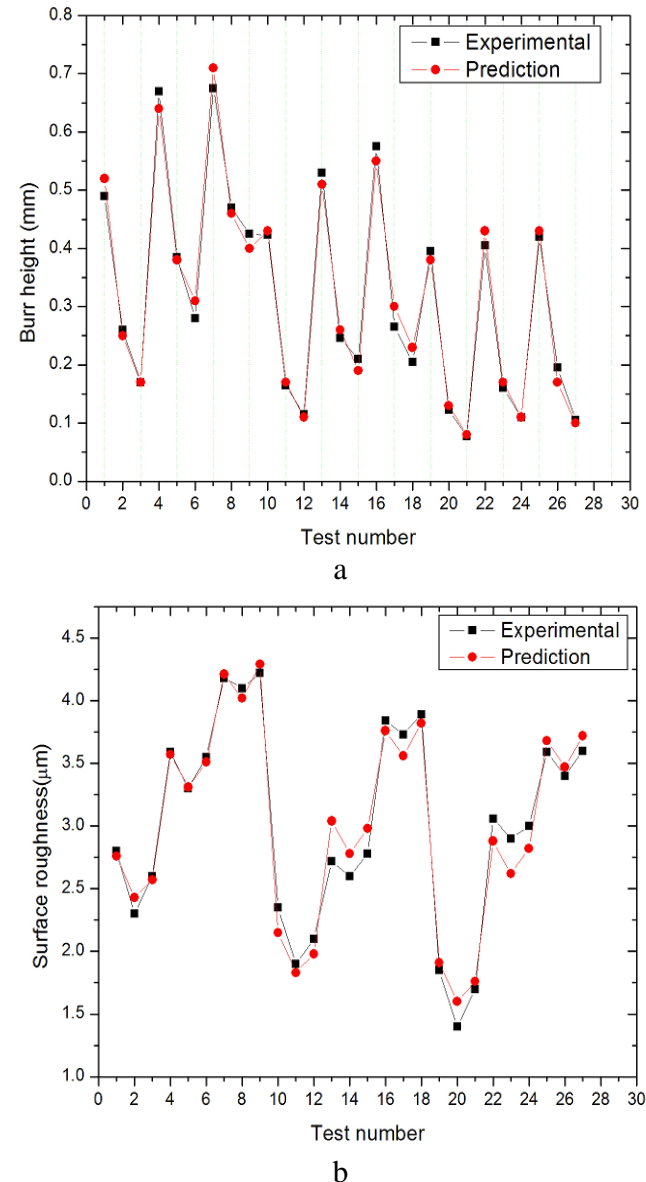

Fig. 6. a - experimental and prediction results plot of burr height; $\mathrm{b}$ - surface roughness

The difference between both the values are calculated and given as the average error percentage, which is for burr height $5.6 \%$ and for surface roughness $4.1 \%$. From the above analysis it was found that optimal parameters for obtaining minimum burr height are $\mathrm{A} 3 \mathrm{~B} 1 \mathrm{C} 3$ and for surface roughness is $\mathrm{A} 3 \mathrm{~B} 1 \mathrm{C} 2$. To verify the optimum machining characteristics of hybrid AMCs, it is important to conduct confirmation tests and chosen levels of parameters for the experiment to provide the desired result. Table 7 shows the reduction in surface roughness and burr height from the initial cutting parameters, which implies that the surface finish and quality of drilled holes have improved. Confirmation test conducted at optimal level and test results compared with predicted model. From that, it is observed that at optimal level, experimental value of surface roughness is $1.64 \mu \mathrm{m}$ and predicted model result is $1.7 \mu \mathrm{m}$. Similarly, for burr height, experiment value is $0.077 \mathrm{~mm}$ and calculated regression model value is $0.08 \mathrm{~mm}$. It can be observed, the calculated error associated with surface roughness is $3.6 \%$ and burr height is $2.3 \%$. So confirmation test results show that developed model is a good agreement with experimental value. Hence, the developed model is suitable to predict the response variable limited to the range of factors considered for this study.

\section{CONCLUSIONS}

The following conclusions can be drawn from the present investigation on drilling of $\mathrm{Al} / 6 \% \mathrm{Al}_{2} \mathrm{O}_{3}$, $\mathrm{Al} / 6 \% \mathrm{Al}_{2} \mathrm{O}_{3} / 1 \% \mathrm{Gr}$ and $\mathrm{Al} / 6 \% \mathrm{Al}_{2} \mathrm{O}_{3} / 2 \% \mathrm{Gr}$ using TiNcoated solid carbide cutting tool at different drilling process parameters:

1. The results indicate that inclusion of graphite as an additional reinforcement in $\mathrm{Al} / 6 \% \mathrm{Al}_{2} \mathrm{O}_{3}$ reinforced composite reduces the burr height. The lowest burr height value was recorded at drilling of $\mathrm{Al} / 6 \% \mathrm{Al}_{2} \mathrm{O}_{3} / 2 \% \mathrm{Gr}$ composite.

2. Graphite is the main factor, which is influencing the burr height in all composites for all machining conditions. The drilling conditions for minimized burr height are identified as: spindle speed $3000 \mathrm{rpm}$ and feed rate $50 \mathrm{~mm} / \mathrm{min}$.

3. Feed rate is the main factor, which influences the surface roughness in drilling of composite and as the feed rate increases the surface roughness also increases. The surface roughness value decreases with the increase in cutting speed in all composites.

4. The lowest surface roughness value observed at the lowest feed rate $(50 \mathrm{~mm} / \mathrm{min})$ with highest cutting speed $(3000 \mathrm{rpm})$ and $1 \mathrm{wt} . \%$ of graphite. Further increase in graphite particles leads to poor surface finish.

5. The chips formed in drilling of graphite reinforced composites is of short length discontinuous chip making it easier for chip disposal and it leads to easy machining.

6. With respect to selected drilling parameters, feed rate contributed more $(79.2 \%)$ for surface roughness followed by speed. On the other hand, graphite percentage played a

7. major role $(58.04 \%)$ to reduce the burr height followed by speed during the investigation on composite drilling.

8. The developed regression models are suitable to find out the surface roughness and burr height of the drilled holes with in the specified range of selected drilling parameters. 


\section{REFERENCES}

1. Goni, J., Mitxelena, I., Coleto, J. Development of Low Costmetal Matrix Composites for Commercial Applications Material Science and Technology 16 2000: pp.743-746.

2. Kök, M. Modelling the Effect of Surface Roughness Factors in the Machining of $2024 \mathrm{Al} / \mathrm{Al}_{2} \mathrm{O}_{3}$ Particle Composites Based on Orthogonal Arrays International Journal of Advanced Manufacturing Technology 55 2011: pp. $911-920$.

3. Hung, N.P., Boey, F.Y.C., Khor, K.A., Oh, C.A., Lee, H.F. Machinability of Cast and Powder-Formed Aluminum Alloys Reinforced with Sic Particles Journal of Materials Processing Technology 48 1995: pp. 291-297.

4. Krishnamurthy, L. Machinability Studies on Metal Matrix Hybrid Composites PhD thesis, Kuvempu University, Karnataka, India: 2009.

5. Tosun, G., Muratoglu, M. The Drilling of $\mathrm{Al} / \mathrm{SiCp}$ Metalmatrix Composites. Part I: Microstructure Composites Science and Technology 64 2004: pp. $299-308$. http://dx.doi.org/10.1016/S0266-3538(03)00290-2

6. Basavarajappa, S., Chandramohan, G., Mahadevan, A., Thangavelu, M., Subramanian, R., Gopalakrishnan, P. Influence of Sliding Speed on the Dry Sliding Wear Behaviour and the Subsurface Deformation on Hybrid Metal Matrix Composite Wear 262 2007: pp. $1007-1012$.

7. Songmene, A.V., Balazinzki, M. Machinibility of Graphitic Metal Matrix Composites As A Function of Reinforcing Particles CIRP Annals 48 (1) 1999: pp.77-80.

8. Basavarajappa, S., Chandramohan, G., Prabu, M., Mukund, K., Ashwin, M. Drilling of Hybrid Metal Matrix Composites-Workpiece Surface Integrity International Journal of Machine Tools and Manufacture 47 2007: pp. 92-96. http://dx.doi.org/10.1016/j.ijmachtools.2006.02.008

9. Sharma, S.C., Girish, B.M., Kulkarni, R.S., Kamath, R. Drillabiliy of Zinc/Graphitic Metal Matrix Composites NML Technology Journal 38 (3) 1996: pp. 107-111.

10. Basavarajappa, S., Davim, J.P. Influence of Graphite Particles on Surface Roughness and Chip Formation Studies in Turning Metal Matrix Composites Materials Research 16 (5) 2013: pp. 990-996.

11. Shanmughasundaram, P., Subramanian, R. Study of Parametric Optimization of Burr Formation in Step Drilling of Eutectic Al-Si Alloy-Gr Composites Journal of Materials Research and Technology 3(2) 2014: pp. $150-157$.

12. Palanikumar, K., Muniaraj, A. Experimental Investigation and Analysis of Thrust Force in Drilling Cast Hybrid Metal
Matrix (Al-15\%Sic-4\%Graphite) Composites Measurement 53 2014: pp. 240-250.

http://dx.doi.org/10.1016/j.measurement.2014.03.027

13. Altunpak, Y., Ay, M., Aslan, S. Drilling of a Hybrid $\mathrm{Al} / \mathrm{Sic} / \mathrm{Gr}$ Metal Matrix Composites International Journal of Advanced Manufacturing Technology 60 (5-8) 2012: pp. $513-517$.

14. Sivasankaran, S., Saminathan, E., $\quad$ Sidharth, S., Harisagar, P.T., Sasikumar, P. Effect of Graphite Addition on Surface Roughness during Turning of AA 7075-Zrb2 InSitu Metal Matrix Composites Procedia Material Science 5 2014: pp. 2122-2131.

15. Basavarajappa, S., Chandramohan, G., Davim, J.P. Some Studies on Drilling of Hybrid Metal Matrix Composites Based on Taguchi Techniques Journal of Materials Processing Technology 196 2008: pp. 332-338.

16. Rajmohan, T., Palanikumar, K., Prakash, S. Grey-Fuzzy Algorithm to Optimise Machining Parameters in Drilling of Hybrid Metal Matrix Composites Composites Part B: Engineering 50 2013: pp. 297-308.

17. Fahlman, B.D. Materials Chemistry - Solid State Chemistry, Springer, Berlin, 2011: pp. 13-156.

18. Gologlu, C., Sakarya, N. The Effects of Cutter Path Strategies on Surface Roughness of Pocket Milling of 1.2738 Steel Based on Taguchi Method Journal of Materials Processing Technology $206(1-3)$ 2008: pp. $7-15$.

19. Ko, S.L., Lee, J.K. Analysis of Burr Formation in Drilling with a New-Concept Drill Journal of Materials Processing Technology 113 (1) 2001: pp. 392-398. http://dx.doi.org/10.1016/S0924-0136(01)00717-8

20. Niknam, S.A., Zedan, Y., Songmene, V. Machining Burrs Formation \& Deburring of Aluminium Alloys- Light Metal Alloys Applications INTECH Open Science 2014: pp. 99-122.

21. Basavarajappa, S., Chandramohan, G., Davim, J.P., Prabu, M., Mukund, K., Ashwin, M., Kumar, M.P. Drilling of Hybrid Aluminium Matrix Composites International Journal of Advanced Manufacturing Technology 35 2008: pp. 1244-1250. http://dx.doi.org/10.1007/s00170-006-0804-z

22. Nway, Z.N., Moonkhan, N.S. Analysis of Physical Health by Estimating Physical Working Capacity of Myanmar Adolescents WIT Transactions on Information and Communication Technologies 58 2014: pp. 509-515. 